ORIGINAL ARTICLE

\title{
Effect of Conventional and Microwave Tissue Processing Technique on DNA Integrity: A Comparative Molecular Analysis
}

\author{
Dhara Dwivedi $^{*}$, Sowmya Kasetty ${ }^{2}$, Manisha S Tijare ${ }^{3}$, Shreenivas Kallianpur ${ }^{4}$, \\ Nitin Prabhakar ${ }^{5}$, Raju Ragavendra $T^{2}$, Ami Desai ${ }^{6}$
}

\section{OPEN ACCESS}

Citation: Dhara Dwivedi, Sowmya Kasetty, Manisha S Tijare, et al. Effect of Conventional and Microwave Tissue Processing Technique on DNA Integrity: A Comparative Molecular Analysis. Ethiop J Health Sci.2018;28(5):615. doi:http://dx.doi.org/10.4314/ejhs.v28i5.13 Received: Januiary 9, 2018

Accepted: January 30, 2018

Published: September 1, 2018

Copyright: (C) 2018 Dhara D., et al. This is an open access article distributed under the terms of the Creative Commons Attribution License, which permits unrestricted use, distribution, and reproduction in any medium, provided the original author and source are credited.

Funding: Nil

Competing Interests: The authors declare that this manuscript was approved by all authors in its form and that no competing interest exists.

Affiliation and Correspondence: ${ }^{1}$ Department of Oral Pathology Dentistry Unit, Ayder Referral Hospital-College of Health Sciences Mekelle University, Ethiopia ${ }^{2}$ Oral pathology Division, Oral Basic and Clinical Sciences, College of Dentistry, Qassim Private College, Buraidah, KSA

${ }^{3}$ Dr. R R Kambe Dental College and Hospital, Ankola, India

${ }^{4}$ People's College of Dental

Sciences and Research Centre

${ }^{5}$ Dept of Oral Maxillofacial

Surgery, Ayder Referral HospitalCollege of Health Sciences, Mekelle University, Ethiopia

${ }^{6}$ People's College of Dental Sciences and Research Centre, Bhopal,Madhya Pradesh, India

*Email: dwivedidhara@gmail.com
BACKGROUND: Methods of diagnostic molecular biology are routinely applied on formalin-fixed, paraffin-embedded tissues processed via conventional method. Recently, there has been a growing interest to use microwave technology in histopathology laboratories to overcome the deficiencies of the conventional processing method. Thefore, this study was aimed to compare and analyze the quality and quantity of DNA obtained from tissues processed by conventional and microwave tissue processing techniques and to further ascertain the applicability of the latter for PCR (polymerase chain reaction based research).

METHODS: Thirty fresh tissues of oral squamous cell carcinoma (OSCC) were included, and each sample was cut into two equivalent halves. One tissue half was processed by conventional manual method whereas the other half was processed using a domestic microwave oven. DNA was obtained from all the tissues which were then subjected to Polymerase chain reaction (PCR) to evaluate GAPDH (Glyceraldehyde-3-phosphate dehydrogenase) gene expression.

RESULTS: The results revealed better DNA yield from microwave processed tissue while the quality of the DNA was alike from both the techniques.

CONCLUSION: On the basis of the results obtained, it can be concluded that DNA produced by microwave processed tissues was similar to that obtained by conventional processing technique in terms of quantity and quality. Thus, microwave processed tissue samples can be successfully used for further molecular studies and researches.

KEYWORDS: Microwave tissue processing, oral squamous cell carcinoma, polymerase chain reaction, GAPDH gene, molecular pathology

\section{INTRODUCTION}

The new-fangled accomplishments in the field of cancer diagnosis have seen a plethora of rapid and accurate high throughput diagnostic tests; these molecular diagnostic tests have now been demonstrated 
to be highly beneficial in the clinical scenario. Recently, there has been a growing interest in using polymerase chain reaction (PCR) to investigate the molecular changes in stepwise progression of various diseases including cancer (1). Lately, DNA extracted from formalin-fixed and paraffin-embedded tissues (FFPE) processed via conventional method has been successfully used for gene analysis by PCR (2).

Routine manual tissue processing (conventional method) method is a reliable and an inexpensive procedure. However, it has many drawbacks including the exposure to noxious chemicals like xylene \& formalin and longer time duration (3).In order to overcome the deficiencies of the conventional method, certain new methods were introduced like automatic tissue processing and microwave method. Of these, microwave tissue processing requires shorter processing time with minimum exposure to noxious chemicals (4). In this process, the penetrative properties of the microwave radiation and the conversion of this incident energy into heat is used; it was first used by Boon and Kok in 1985 (3).

Since this technology was first adopted in pathology laboratories, many studies have been conducted and have already established the creditability of this technique for efficient tissue fixation and processing. However, no study has been conducted to compare the quality and quantity of the DNA obtained from the oral squamous cell carcinoma tissues, processed by conventional manual processing technique and microwave processing method and to further evaluate the viability of the procured DNA to be utilized for further molecular investigations. Thus, this study was intended to assess the PCR results of GAPDH gene expression in the extracted DNA samples and thereby to compare and analyze the effects of the microwave histoprocessing on DNA integrity and its applicability when compared with routine tissue processing techniques.

\section{METHODS}

Formalin fixed OSCC tissue specimen formalin stored for less than 6 months were collected from the archives of People's College of Dental Sciences \& Research Centre, Bhopal and Jawaharlal Nehru Cancer Hospital, Bhopal (India). Approval was obtained from the ethical committee of the involved institutes. Subsequent DNA analysis was performed in the Centre for Scientific Research and Development People's Group, Bhopal (India). Each sample was cut into two equal halves with each tissue bit measuring approximately $1.0 \times 1.0 \times 0.5 \mathrm{~cm}$ and fixed in $10 \%$ formalin for 24 hours. The samples were then grouped as following:

\section{Tissue processing}

Group A: The specimens were processed using the conventional method i.e. dehydrated in increasing concentrations of alcohol, cleared in xylene, impregnated in paraffin wax using hot air oven (Table1).

Group B: The tissue samples were washed under running tap water to remove formalin. They were then placed in a plastic cassette and transferred to microwave oven safe glass containers with the capacity of $500 \mathrm{ml}$ containing $200 \mathrm{ml}$ of the absolute isopropyl alcohol. A water load of $200 \mathrm{ml}$ was placed in another microwave resistant beaker of capacity of $500 \mathrm{ml}$. The two beakers were placed together in microwave oven which was operated at $40 \%$ power for two 20 minutes cycle. For impregnation procedure, the tissue was shifted to a beaker containing $200 \mathrm{ml}$ paraffin wax. This beaker along with the $200 \mathrm{ml}$ water load in another beaker was placed in microwave oven and run at $40 \%$ power for two cycles of 20 minutes. Minimal gap was kept between the two steps to avoid tissue desiccation. The procedure that was followed is given in Table 2.

DOI: http://dx.doi.org/10.4314/ejhs.v28i5.13 
Table 1: Protocol for conventional tissue processing

\begin{tabular}{ccc}
\hline Steps & Reagents & Duration (Minutes) \\
\hline Dehydration & $70 \%$ Isopropyl alcohol & 60 \\
& 80\% Isopropyl alcohol & 60 \\
& $90 \%$ Isopropyl alcohol & 60 \\
& 100\% Isopropyl alcohol & 60 \\
Clearing & Xylene & 60 \\
& Xylene & 60 \\
Impregnation & Paraffin wax & 60 \\
& Total duration : 24 hours & Overnight \\
\hline
\end{tabular}

Table 2: Protocol for microwave tissue processing

\begin{tabular}{ccc}
\hline Steps & Reagent Used & Duration (Minutes) \\
\hline Dehydration & Absolute isopropyl alcohol & 20 \\
& Absolute isopropyl alcohol & 20 \\
Impregnation & Paraffin wax & 20 \\
& Paraffin wax & 20 \\
& Total duration : 1hr 10 mins & \\
\hline
\end{tabular}

Tissues obtained after processing by both techniques were then embedded in paraffin wax using L molds. Hematoxylin and Eosin (H\&E) stained sections were prepared; only those samples with diagnosis of squamous cell carcinoma were taken for the study.

Sample preparation for PCR: About $25 \mu \mathrm{m}$ thick sections were collected from paraffin embedded tissue blocks; 30 tissues in a given sample were kept constant. Sections were then transferred into $1.5 \mathrm{ml}$ micro-centrifuge tube for DNA extraction procedure.

DNA extraction: Xylene method was employed for the deparaffinization of paraffin-embedded tissues followed by the treatment with series of chilled graded ethanol washes $(100 \%, 80 \%$ and $70 \%$ ) centrifuged at $12,000 \mathrm{rpm}$ for 10 minutes in micro centrifuge machine (Micro Centrifuge EPPENDORF-5804 R) to obtain tissue pellets. For protein digestion, $40 \mu \mathrm{l}$ Proteinase $\mathrm{K}$ was employed. After proteinase $\mathrm{K}$ inactivation, DNA isolation was performed employing Phenol: Chloroform (Conventional) method. Later, DNA purification was carried out with alcohol. The yield of DNA was measured using a Picodrop UVSpectrophotometer (PICOPET01 manufactured by Picodrop Ltd - Cambridge, U.K.) at 260nm with TE buffer; $1 \mu$ of eluted DNA was taken in the pipette and the absorbance of various samples was obtained.

PCR was performed using two different primer sets for the GAPDH gene, amplifying (96 base pairs) products; PCR fragments were amplified using the same forward primer (5'CCCCACACACATGCACTTACC-3') and reverse primers CCTAGTCCCAGGGCTTTGATT-3') procured from Integrated DNA Technologies (IDT, USA). The amplification was programmed in an eppendorf master cycler gradient as detailed in Table 3. 
Table 3: PCR programme for GAPDH primer

\begin{tabular}{llllll}
\hline Step no. & Events & & Temperature & Duration & \\
\hline 1 & Initial Denaturation & & $95^{\circ} \mathrm{C}$ & $5 \mathrm{mins}$ & \\
2 & Amplification & Denaturation & $95^{\circ} \mathrm{C}$ & $1 \mathrm{~min}$ & 45 Cycles \\
& & Annealing & $60^{\circ} \mathrm{C}$ & $1 \mathrm{~min}$ & \\
& & Extension & $72^{\circ} \mathrm{C}$ & $1 \mathrm{~min}$ & \\
3 & Final extension & & $72^{\circ} \mathrm{C}$ & $10 \mathrm{mins}$ & \\
\hline
\end{tabular}

Electrophoresis and Analysis of PCR Product: The PCR products were loaded carefully into well of the casted gel, with controls (distilled water instead of template DNA) to test the purity and viability of reagents. Gel Electrophoresis Unit (AXYGEN, USA) was employed for the same. The analysis was performed for all the samples at least three times with each selected primers to check the reproducibility. A DNA ladder was also loaded along with the samples to quantify DNA, and electrophoresis was carried out at a constant voltage of $70 \mathrm{~V}$ till the dye ran 3/4th distance on the gel. After the gel was ran it was placed on gel documentation system and was visualized by 302 $\mathrm{nm}$ high intensity UV light. Image was captured and analyzed by using Quantity One Software (Figures 1, 2). Molecular weight was calculated by using this software.

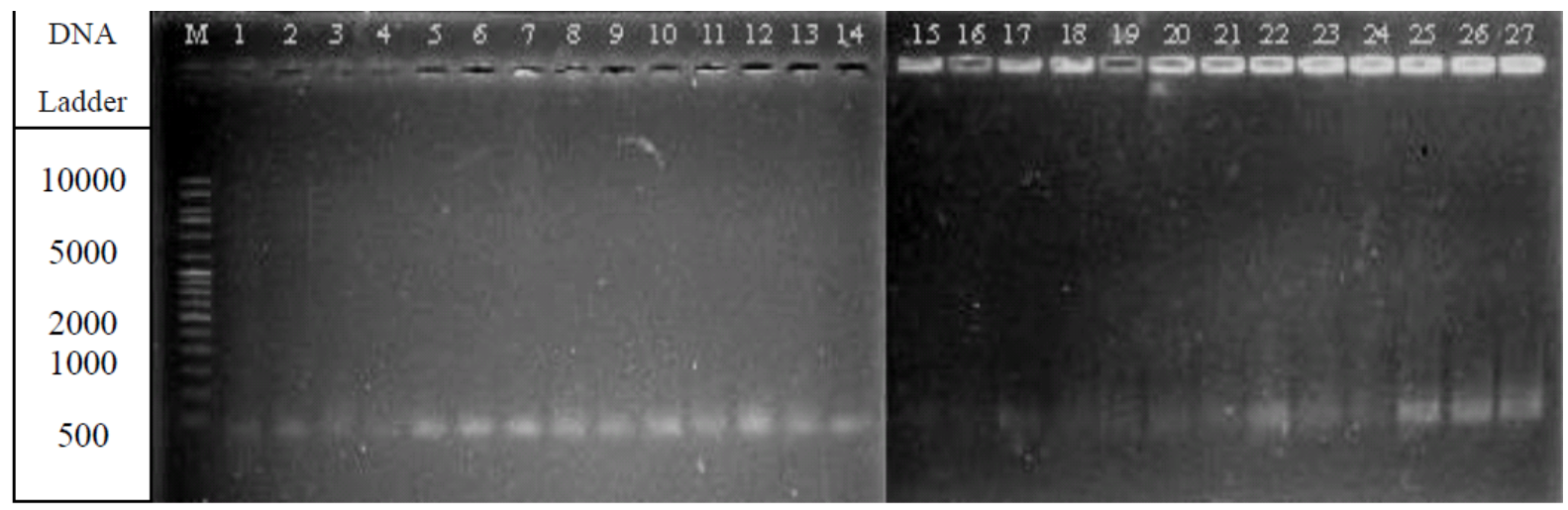

Figure 1: An agarose gel chromatograph showing GAPDH gene profile of the 30 DNA samples obtained from conventionally processed tissue under group A of the study; M,100bp DNA ladder

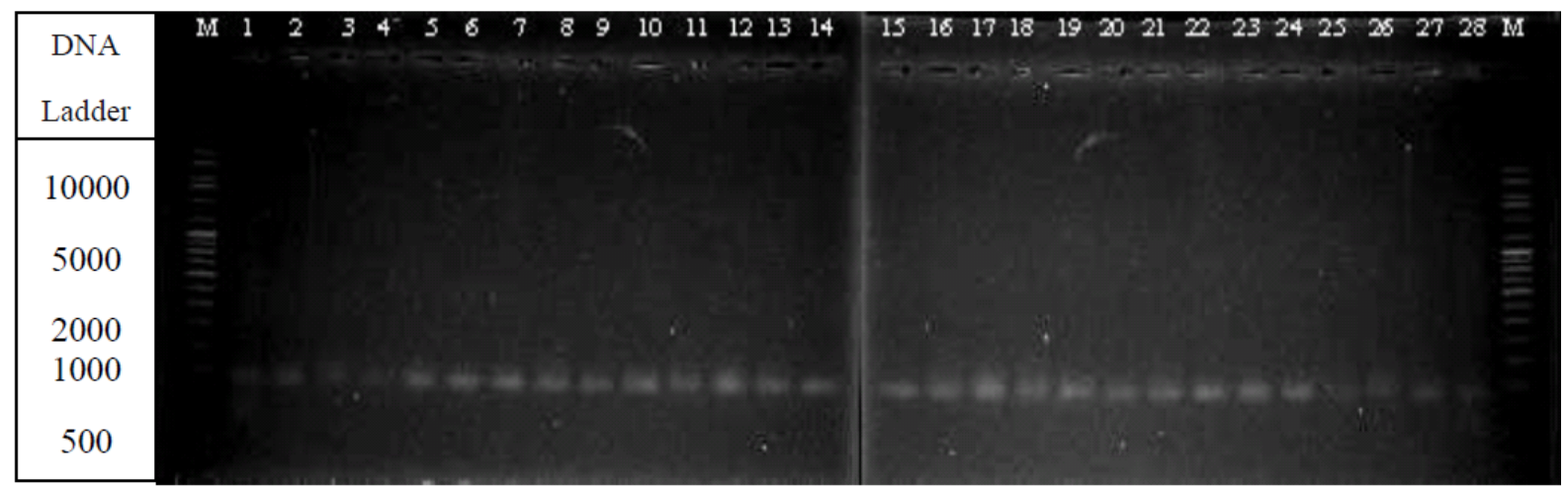

Figure 2: An agarose gel chromatograph showing GAPDH gene profile of the 30 DNA samples obtained from microwave processed tissue under group B of the study; M,100bp DNA ladder 


\section{RESULTS}

Statistical analysis was carried out to establish correlation between the two study groups for qualitative and quantitative assessment of the obtained DNA. Statistical difference was assessed by means of paired and unpaired t-test and Pearson chi-square tests using SPSS software.

Purity of extracted DNA: The purity of the obtained DNA was estimated by calculating the ratio of absorbance at $260 \mathrm{~nm}$ and $280 \mathrm{~nm}$ measured using PicoDrop UV-Spectrophotometer. The ratio between 1.6 and 1.8 indicates the presence of nucleic acids. A ratio of less than 1.6 indicates additional presence of protein content and greater than 1.8 indicates RNA content or chloroform and phenol contamination.Samples with uncontaminated DNA (purity of 1.6-1.8) were more in group B; although Chi-Square test analysis demonstrated insignificant difference between the two groups. Difference between the two groups was calculated by applying unpaired ttest, and the P-value was found to be insignificant (Table 4).

Table 4: Samples with the possible contamination in both groups (Chi-Square Test Analysis)

\begin{tabular}{ccccccc}
\hline Groups & $\begin{array}{c}\text { Sample } \\
\text { size } \\
\text { (n) }\end{array}$ & $\begin{array}{c}\text { No } \\
\text { Contamination } \\
\mathbf{n}(\%)\end{array}$ & $\begin{array}{c}\text { Protein } \\
\text { Contamination n } \\
(\%)\end{array}$ & $\begin{array}{c}\text { RNA } \\
\text { Contamination } \\
\text { n (\%) }\end{array}$ & $\begin{array}{c}\text { Chi - Square } \\
\text { value }\end{array}$ & $\begin{array}{c}\text { P - } \\
\text { value }\end{array}$ \\
\hline $\begin{array}{c}\text { Group } \\
\quad\end{array}$ & 30 & $12(40 \%)$ & $18(60 \%)$ & 0 & 0.606 & 0.436 \\
$\begin{array}{c}\text { Group } \\
\text { B }\end{array}$ & 30 & $15(50 \%)$ & $15(50 \%)$ & 0 & & \\
\hline
\end{tabular}

n: Number of Samples, NS: Non Significant, P Values $<0.05$ and $<0.01$ are statistically significant and $\mathrm{P}$ value $<0.001$ is highly significant

Quantity of extracted DNA: The mean quantities of the DNA extracted from the group B samples produced much higher mean DNA yield than group A. The outcome of unpaired t-test analysis revealed a significant relationship in the discrepancy between the two groups. Also, ChiSquare test was performed for the pairwise comparison of DNA quantity of the individual sample of the two groups which interprets that the numbers of the sample with the better DNA outturn were more in group B than in group; the $p$ value $=0.002$ was significant. In this study, the minimum tissue weight from which the DNA could be efficiently extracted was as little as $6 \mathrm{mg}$ and $2 \mathrm{mg}$ of the conventionally and microwave processed tissue respectively.

Quality of extracted DNA - PCR amplifications in different groups: Quality of the DNA was assessed by observing its potential to be amplified. Although tissue samples of both the groups were successfully amplified, group B tissues revealed more number of amplification compared to group
A. Furthermore, the minimum quantities of the DNA which could be successfully amplified were $7.91 \eta \mathrm{g} / \mu \mathrm{l} \& 10.85 \mathrm{\eta g} / \mu \mathrm{l}$ of the conventional and microwave processed specimens.

\section{DISCUSSION}

Oral squamous cell carcinoma (OSCC) is the eighth most common cancer worldwide associated with significant morbidity and mortality (5). Currently, oral carcinogenesis is hypothesized to be governed by the accretion of the genetic mutations affecting the structure and function of the genome at molecular level along with equally important epigenetic changes $(6,7)$. Thus, genetic and genome based approaches have established themselves as the linchpin in the diagnosis and prognosis of oral cancer (8). Central to molecular diagnostics and assays are the nucleic acids (9). Amplification of nucleic acid sequences has brought new insights into the etiology of cancer that has proved to be highly useful for early

DOI: http://dx.doi.org/10.4314/ejhs.v26i5.13 
detection, diagnosis and treatment $(10,11)$; PCR being the method for the in vitro amplification of specific nucleic acid sequences has now become the mainstay of the use of molecular science in diagnosis and research (12). PCR provides with fine sensitivity that enables the molecular study of fixed paraffin-embedded tissue (PET) specimens, which comprise most archival clinical material. The extraction of nucleic acids from routinely fixed and processed tissue is particularly important as it permits the use of archival material for the retrospective investigation of disease (13).

In spite of the tremendous advances made in the field of histoprocessing techniques, the majority of the laboratories continue to practice a century old technique for preserving and processing tissue specimen i.e. Formaldehyde fixation followed by conventional processing method. The conventional manual tissue processing technique requires a minimum of 8-16 hours, thereby causing a 1-day minimum delay in drawing the diagnosis (14). Furthermore, the use of toxic chemical reagents like xylene is the other important shortcoming associated with this technique. Exposure to xylene can occur via inhalation, ingestion, eye or skin contact with the probable damage to multiple body systems making it a potential occupational hazard for the histopathological technicians (15).

Microwave tissue processing technique has surfaced as an antidote to all these obstacles. Although microwaves were invented by Percy Spencer in 1945; it was Mayers who pioneered the use of microwave technology in histologic procedures in 1970s $(16,17)$. Understanding the technology and its various applications is the two most essential components which determine its overall success or failure. Microwaves are nonionizing radiations with electromagnetic properties with the frequencies ranging from $300 \mathrm{MHz}$ to $300 \mathrm{GHz}$ and wavelengths from $1 \mathrm{~mm}$ to $1 \mathrm{~m} \mathrm{(18)}$.

As the microwaves penetrate into the tissues, the energy is absorbed by the water molecules. In the oscillating electric fields produced by microwaves irradiation, the dipolar molecules like water are forced to vibrate. Some of the acquired rotational energy is transferred to the random motion upon collision with other molecules. This induced kinetic movement produces instantaneous heat which further increases the diffusion of the reagents and thereby decreases the tissue processing time. Unlike conventional heating, heating in microwave is from within (internal heating), and its effect occurs throughout the material being irradiated (19).

\section{Microwave aided tissue processing}

Temperature: The physicochemical basis of tissue processing lies in the diffusion of reagents into the substance of the tissue to be processed. This higher temperature facilitates diffusion, thereby allowing quicker tissue processing. Although the risk of tissue damage is there due to higher temperature, short exposure time does not allow that to happen. In this study, all the three steps of processing were carried out in 2 changes of $200 \mathrm{ml}$ of reagents for 20 minutes. Therfore, in order to prevent any kind of tissue damage, a water load of $200 \mathrm{ml}$ was also kept during every procedure.

The commercially available microwave ovens are designed to provide precise control of specimen temperature which domestic ovens cannot. Kok et al recommend $67^{\circ} \mathrm{C}$ to be suitable for dehydration temperature while the following procedures were carried out between the range of $60^{\circ} \mathrm{C}$ to $82^{\circ} \mathrm{C}(20)$. Babu TM et al and Kango and Deshmukh used a domestic microwave oven in which the maximum temperature reached was $87^{\circ} \mathrm{C}$ and $58^{\circ} \mathrm{C}$ respectively. Stepwise assessment of the tissue temperature could not be recorded in this study, but the highest temperature attained was $84^{\circ} \mathrm{C}(16,21)$.

Reagents: Depending upon their ability to absorb the microwave energy, some materials can be more microwavable than others. In this study, both dehydration and clearing were performed using iso propyl alcohol as it presents with various advantages over the others. These include:

1. better ability to absorb the microwave energy i.e. more microwavable;

2. safer than the toxic chemicals like xylene;

3. boiling temperature of $82^{\circ} \mathrm{C}$ allows it to boil out readily in paraffin impregnation procedure; 
4. its dehydrating property; and

5. Miscible in water.

Besides, iso propyl alcohol, use of the other reagents such as graded alcohol and chloroform has also been suggested by some authors. However, in this study, iso propyl proved to be an effective dehydrant and clearing agent.

Size of the specimen: The basic effect of microwave irradiation is stimulation of diffusion and enhancement of reaction rates with internal heating being the key element in the process. The formula which governs the rate of diffusion is $<\mathrm{X} 2$ $>=2 \mathrm{Dt}$, where $\mathrm{x}$ stands for net distance covered by a particle in solution in a certain direction; it is the time period during which diffusion occurs; D is the diffusion constant for the substance and $<>$ stands for the average value. This implies that the average squared distance covered by a particle in solution is proportional to the diffusion time (22). This shows the need to keep the thickness of the biopsies small: three times as thick means nine times as long for comparable effects. Kok et al reiterated the importance of the thickness of the tissue to be irradiated and mentioned that it was the thickness and not the length or width of the tissue that mattered. They also mentioned that microwaves can penetrate upto a maximum depth of $2 \mathrm{~cm}$, as the larger specimens would require additional cycles (16). Therefore, all the specimens selected for this study were less than $1 \times 1 \times 0.5 \mathrm{~cm}$ in thickness (less than $2 \mathrm{~cm}$ ).

In this study, DNA purity was the first parameter studied and compared. It was found that $50 \%$ of the microwave processed tissues contained pure DNA compared to only $40 \%$ of conventionally processed tissues showing uncontaminated DNA. These results are in accordance with findings of Bodor et al who were able to obtain the genomic DNA with a purity of 1.6-1.7 OD260/OD280 from both of the processing techniques evaluated in this study (23). Also, Hsu et al were able to retrieve excellent quality DNA from in situ hybridization when microwave fixed tissue were used, further supporting the outcome of this study (24). However, Aydin I et al found differing results; the DNA they obtained from formaldehyde fixed microwaved processed tissue was fragmented and not of good quality (25).

The quantity of DNA is as important as its quality for subsequent molecular analysis; the second factor which was evaluated. After the interpretation of the data obtained, it was evident that the tissues processed utilizing the microwave method were able to produce much higher DNA than the routinely processed tissue by the conventional method. Banarjee SK et al and Aydin et al who had described a microwave based DNA extraction procedure from FFPE tissues arrived at a similar conclusion i.e. the derived DNA was of sufficient quantity $(25,26)$. This parameter was also studied by Bodor et al who were successfully able to extract good quality and quantity of DNA after having the tissue processed by microwave apparatus (23).

Apart from these, literature accommodates a few more researches which have highlighted the utility of the microwave for fruitful extraction of DNA. Lou et al reported that microwave treatment of the sample (cervivaginal lavage in this case) lead to adequate production of HPV DNA for its detection by PCR. They concluded that the higher denaturation temperature required for more efficient DNA extraction was better provided by microwave than by the conventional method in a short span of time and without much damage to the tissues; thus, emphasizing its utility for the same (27).

Lastly, the quality of the extracted DNA was estimated as a measure of number of samples with amplifiable DNA. On the basis of the results of the GAPDH gene expression post PCR, it can be stated that DNA retrieved from microwave method can be as effectively amplified as those processed by the conventional overnight technique; hence, equally good quality from both the technique. Likewise, conclusions were drawn by Banarjee et al and Bodor et al who carried out positive amplification of ki-ras and $\beta$-globin gene in human tissues via PCR $(23,26)$. These results were further in congruence with the findings of Aydin et al, who reported successful PCR amplification of the DNA from microwave processed tissues (25). 
The practice of microwave assisted tissue processing has brought about a reassessment of traditional concepts by simplifying the paradigm of prolonged durations of conventional histoprocessing methods and curtailing it to several minutes. As evidenced by the results of this study, we were able consolidate microwave technology with the molecular biology techniques to prepare the formalin fixed tissues for the procurement of DNA with well preserved integrity and its further use for molecular procedures.

Apart from its use in tissue processing, it has also been found to be profoundly effectual in tissue fixation, tissue section staining, antigen preservation and electron microscopy. Studies have established that the quality of microwaveprocessed and microwave-stained slides is identical or slightly better than conventionally processed and stained slides $(18,21,22,28,29,30)$. Also, microwave technology has immensely contributed in the successful antigen retrieval as well as enhanced immunostaining in immunohistochemical procedures $(18,30,31,32)$, it has been a significant addition to the DNA extraction methods too $(34,35,36)$.

Ten percent formaldehyde was used in this study as the tissue fixative is known to cause degradation of the nucleic acids. In pursuance of overcoming this impediment, further studies incorporating less harmful alternative fixatives along with microwave histoprocessing technique is recommended.

\section{REFERENCES}

1. Tufan NLS, Bir F, Duzcan E.Rapid and effective DNA amplification by polymerase chain reaction directly from paraffinembedded tissue. Aegean Pathology Journal, 2004;1:33-38.

2. Srinivasan M, Sedmak D, Jewell S. Effect of fixatives and tissue processing on the content and integrity of nucleic acids. Am J Pathol, 2002;161:1961-71.

3. Sengüven B, Baris E, Oygur T, Berktas M. Comparison of methods for the extraction of
DNA from formalin-fixed, paraffin-embedded archival tissues. Int J Med Sci. 2014 Mar 27;11:494-9.

4. Koshiba M, Ogawa K, Hamazaki S, Sugiyama $\mathrm{T}$, Ogawa $\mathrm{O}$, Kitajima $\mathrm{T}$. The effect of formalin fixation on DNA and the extraction of high-molecular-weight DNA from fixed and embedded tissues. Pathol Res Pract, 1993 Feb;189(1):66-72.

5. India Project Team of the International Cancer Genome Consortium. Mutational landscape of gingivo-buccal oral squamous cell carcinoma reveals new recurrently-mutated genes and molecular subgroups. Nat Commun, 2013;4:2873.

6. Herceg Z, Hainaut P. Genetic and epigenetic alterations as biomarkers for cancer detection, diagnosis and prognosis. Mol Oncol, 2007;1:26-41.

7. Mascolo M, Siano M, Ilardi G, Russo D, Merolla F, De Rosa G, Staibano S. Epigenetic disregulation in oral cancer. Int $J$ Mol Sci, 2012;13(2):2331-53.

8. Bhatt AN, Mathur R, Farooque A, Verma A, Dwarakanath BS. Cancer biomarkers - current perspectives. Indian J Med Res, 2010 Aug;132:129-49.

9. Kononen J, Bubendorf L, Kallioniemi A, Bärlund M, Schraml P, Leighton S, Torhorst J, Mihatsch MJ, Sauter G, Kallioniemi OP. Tissue microarrays for high-throughput molecular profiling of tumor specimens. Nat Med, $1998 \mathrm{Jul}$;4(7):844-7.

10. National Laboratory of Enteric Pathogens, Bureau of Microbiology, Laboratory Centre for Disease Control. The polymerase chain reaction: An overview and development of diagnostic PCR protocols at the LCDC. Can J Infect Dis, 1991;2:89-91.

11. Bermingham N, Luettich K. Mini-symposium: Advances in laboratory practice.Polymerase chain reaction and its applications. Current diagnostic pathology, 2003 9, 159-164.

12. Loeffelholz M, Deng H. PCR and Its Variations. Advanced Techniques in Diagnostic Microbiology, 2006:166183. 
13. Malhotra KT, Gulati U, Balzer B, Wu HY Comparison of DNA Extraction Methods from Formalin-Fixed, Paraffin-Embedded Tissue and their Impact on Real-Time PCR-Based Mutation Assays. $J$ Med Diagn Meth, 2012;1:1-6

14. Mohammah Raza Hafazi Ahmadi, Ali Mohammad Bahrami, Ehsan Hosseini . Evaluating Tissue Cross section Method by Microwave Energy, using different Tissue organs of the Broiler and Sheep as a Modal. Adv. Biores, 2013;4:109-114.

15. Kandyala R, Raghavendra SP, Rajasekharan ST. Xylene: An overview of its health hazards and preventive measures. J Oral Maxillofac Pathol, 2010:14 (1):1-5.

16. Kango PG, Deshmukh R. Microwave processing: A boon for oral pathologists. $J$ Oral Maxillofac Pathol, 2011;15:6-13.

17. Mayers CP. Histological fixation by microwave heating. $J$ Clin Pathol, 1970;23(3):273-5.

18. Shruthi BS, Vinodhkumar P, Kashyap B, Reddy PS. Use of microwave in diagnostic pathology. J Cancer Res, Ther 2013;9:351-5

19. Leong AS. Microwaves and turnaround times in histoprocessing: is this a new era in histotechnology? Am J Clin Pathol, 2004; $121: 460-2$.

20. Kok LP, Visser PE, Boon ME. Histoprocessing with the microwave oven: an update. Histochem J, 1988;20:323-8.

21. Babu TM, Malathi N, Magesh KT. A comparative study on microwave and routine tissue processing. Indian $J$ Dent Res, 2011;22:50-5.

22. Kumar H, Kalkal P, Buch A, Chandanwale SS, Bamanikar S, Jain A. Role of microwaves in rapid processing of tissue for histopathology. Med $J$ DY Patil Univ, 2014;7:458-62

23. Bödör C, Schmidt O, Csernus B, Rajnai H, Szende B. DNA and RNA isolated from tissues processed by microwave-accelerated apparatus MFX-800-3 are suitable for subsequent PCR and Q-RT-PCR amplification. Pathol Oncol Res, 2007;13:149-52.
24. Hsu HC, Peng SY, Shun CT, et al: High quality of DNA retrieved for Southern blot hybridization from microwavefixed, paraffinembedded liver tissues. J Virol Methods, 1991;31:251-261.

25. Aydin I, Yörükoglu K, Cingöz S, Agilkaya S. The effect of the alternative solutions to formaldehyde and xylene on tissue processing. Indian J Pathol Microbiol, 2013;56:221-30.

26. Banerjee SK, Makdisi WF, Weston AP, Mitchell SM, Campbell DR. Microwavebased DNA extraction from paraffinembedded tissue for PCR amplification. Biotechniques, 1995;18:768-70

27. Lou YK, Qin H, Molodysky E, Morris BJ. Simple microwave and thermal cycler boiling methods for preparation of cervicovaginal lavage cell samples prior to PCR for human papillomavirus detection. J Virol Methods, 1993;44:77-81.

28. Kartesh Singla, Simarpreet Virk Sandhu, Rana A. G. K. Pal, Himanta Bansal, Ramanpreet Kaur Bhullar, Preetinder Kaur. Comparative evaluation of different histoprocessing methods. International Journal of Health Sciences. 2017;11:2

29. Mathai AM, Naik R, Pai MR, Rai S, Baliga P. Microwave histoprocessing versus conventional histoprocessing. Indian $J$ Pathol, Microbiol. 2008 Jan-Mar;51(1):12-6.

30. Katoh K. Microwave-Assisted Tissue Preparation for Rapid Fixation, Decalcification,Antigen Retrieval, C ryosectioning, and Immunostaining. Int J Cell Biol, 2016; 2016: 7076910.

31. Lyska L. Emerson, Sheryl R. Tripp, Bradley C. Baird, MStat, Lester J. Layfield, L. Ralph Rohr. A Comparison of Immunohistochemical Stain Quality in Conventional and Rapid Microwave Processed Tissues. Am J Clin Pathol, 2006; 125:176-183.

32. Cattoretti G, Pileri S, Parravicini C, et al. Antigen unmasking on formalin fixed, paraffin-embedded tissue sections. The Journal of pathology, 1993;171:2

DOI: http://dx.doi.org/10.4314/ejhs.v26i5.13 
33. Shi SR, Key ME, Kalra KL Antigen retrieval in formalin-fixed, paraffin-embedded tissues: an enhancement method for immunohistochemical staining based on microwave oven heating of tissue sections. $J$ Histochem Cytochem, 1991;39 (6):741-8.

34. Sato Y, Sugie R, Tsuchiya B, Kameya T, Natori M, Mukai K.Comparison of the DNA extraction methods for polymerase $\mathrm{c}$ hain reaction amplification from formalinfixed and paraffin-embedded tissues. Diagn Mol Pathol, 2001;10(4):265-71.

35. Iesurum A, Balbi T, Vasapollo D, Cicognani A, Ghimenton C. Microwave processing and ethanol-based fixation in forensic pathology. Am J Forensic Med Pathol, 2006;27(2):178-82.

36. M.S.C. Netto, A.L.C. Alves, E.F. Carvalho, R.G. Garrido, D.A. Silva. DNA extraction and purification from archival material: Revisiting the standard operating procedure Forensic Science International. Genetics Supplement Series, 20155;e574-e575 